KONSTAN
JURNAL FISIKA DAN PENDIDIKAN FISIKA
Volume 4, Nomor 1, Juni 2019
$\begin{array}{r}\text { E-ISSN : 2460-9129 dan P-ISSN : 2460-9110 } \\ \text { http://jurnalkonstan.ac.id/index.php/jurnal }\end{array}$

\title{
PENGARUH MODEL PEMBELAJARAN BERBASIS MASALAH DAN PENGETAHUAN AWAL TERHADAP KEMAMPUAN BERPIKIR KRITIS FISIKA PESERTA DIDIK KELAS X
}

\author{
Isti Ayua Diani $^{1}$, Satutik Rahayu ${ }^{1 *}$, Ni Nyoman Sri Putu Verawati ${ }^{1}$ \\ ${ }^{1}$ Program Studi Pendidikan Fisika FKIP Universitas Mataram \\ Jalan Majapahit No. 62 Mataram
}

\section{Info Artikel}

Sejarah Artikel:

Diterima Desember 2019

Disetujui Juni 2019

Dipublikasikan Juni 2019

\section{Kata Kunci:}

Model pembelajaran

berbasis

masalah, pengetahuan awal, dan kemampuan berpikir kritis.

\begin{abstract}
Abstrak
Berpikir kritis merupakan proses kemampuan yang dilibatkan dalam membuat keputusan secara rasional yang harus dilakukan dan apa yang harus dipercaya. Kemampuan berpikir kritis masih dianggap hal baru bagi guru dan peserta didik. Penelitian ini bertujuan untuk mengetahui pengaruh model pembelajaran berbasis masalah terhadap kemampuan berpikir kritis fisika peserta didik kelas $\mathrm{X}$ dan pengaruh pengetahuan awal terhadap kemampuan berpikir kritis Fisika peserta didik kelas $\mathrm{X}$, serta untuk mengetahui interaksi antara model pembelajaran berbasis masalah dan pengetahuan awal terhadap kemampuan berpikir kritis Fisika peserta didik kelas X. Jenis penelitian ini adalah penelitian kuasi eksperimen dengan desain penelitian Factorial Design $2 \times 2$. Populasi penelitian menggunakan seluruh peserta didik kelas $X$ MIA SMA Negeri 1 Kediri. Pengambilan sampel penelitian menggunakan teknik cluster random sampling. Pengumpulan data pengetahuan awal peserta didik menggunakan tes pilihan ganda dan pengumpulan data kemampuan berpikir kritis peserta didik menggunakan tes uraian. Data hasil dianalisis menggunakan uji hipotesis anava dua jalan dengan taraf signifikansi 5\%. Hasil penelitian menunjukkan bahwa ada pengaruh model pembelajaran berbasis masalah dan pengetahuan awal terhadap kemampuan berpikir kritis Fisika peserta didik kelas X. Selain itu, tidak ada interaksi antara model pembelajaran berbasis masalah dan pengetahuan awal terhadap kemampuan berpikir kritis Fisika peserta didik kelas X.
\end{abstract}

(C) 2019 Universitas Islam Negeri Mataram

\footnotetext{
* Corresponding Author: satuti@ yahoo.com
}

Alamat korespodensi:

Gedung Pasca Sarjana Lantai 3 Kampus 2 UIN Mataram, Jl. Gajah Mada 100 Jempong Mataram, Indonesia

Email: jurnalkonstan@uinmataram.ac.id 


\section{PENDAHULUAN}

Kurikulum memberikan kontribusi yang sangat besar dalam meningkatkan kualitas lulusan peserta didik. Sejak tahun pelajaran 2013/2014 mulai diterapkan kurikulum 2013 untuk menyempurnakan Kurikulum Tingkat Satuan Pendidikan (KTSP). Kurikulum 2013 diharapkan dapat mengembangkan keterampilan peserta didik dalam belajar dan berinovasi, yang meliputi kemampuan berpikir kritis, kemampuan menyelesaikan masalah, kreatif dan inovatif, serta mampu berkomunikasi dan berkolaborasi. Namun tujuan diterapkannya kurikulum 2013 ini masih belum tercapai sepenuhnya.

Berdasarkan hasil wawancara di SMAN 1 Kediri, guru yang mengajarkan Fisika belum pernah melakukan pengukuran terhadap kemampuan berpikir kritis peserta didik. Kemampuan berpikir kritis masih dianggap hal baru bagi guru dan peserta didik. Padahal meningkatkan kemampuan berpikir kritis peserta didik merupakan salah satu upaya untuk meningkatkan keterampilan belajar dan inovasi peserta didik yang sesuai dengan tujuan diterapkannya kurikulum 2013. Berpikir kritis merupakan proses kemampuan yang dilibatkan dalam membuat keputusan secara rasional yang harus dilakukan dan apa yang harus dipercaya [1]. Indikator berpikir kritis yang digunakan pada penelitian ini, yaitu: klarifikasi dasar, keputusan dasar, inferensi, penjelasan lebih lanjut, serta menalar dan pengintegrasian [2]. Selain itu, masih ditemukan proses pembelajaran yang berpusat terhadap guru sehingga peserta didik cenderung diam dan hanya mendengarkan penjelasan guru. Selama proses pembelajaran guru juga kurang memperhatikan pengetahuan awal peserta didik, sehingga peserta didik beranggapan bahwa materi Fisika yang dipelajari tidak saling berkaitan dan cenderung meremehkan beberapa materi Fisika yang diajarkan.

Pengetahuan awal merupakan pengetahuan peserta didik sebelum mempelajari suatu materi pembelajaran di sekolah. Pengetahuan awal yang dimiliki peserta didik dikonstruksi berdasarkan pengalaman, pembelajaran yang didapatkan sebelumnya, fenomena-fenomena lingkungan dan lain sebagainya. Pengetahuan awal merupakan hal penting yang perlu dipertimbangkan, tetapi sangat jarang ada guru yang menerapkan proses pengukuran pengetahuan awal peserta didik [3]. Guru juga harus memperhatikan pengetahuan awal dari materi yang akan dipelajari oleh peserta didik untuk dapat menciptakan proses pembelajaran yang lebih efektif. Kualitas pengetahuan peserta didik akan memberikan dampak yang baik pada kemampuan peserta didik dalam memahami materi pelajaran.

Berdasarkan pemaparan yang telah diuraikan, maka perlu dilakukan perbaikan dalam kegiatan pembelajaran dengan cara menerapkan model pembelajaran yang sesuai untuk mengembangkan kemampuan berpikir kritis 
peserta didik dan mengaplikasikan pengetahuan awal yang dimiliki peserta didik untuk memberikan gambaran mengenai konsep dan prinsip tentang materi baru yang akan diberikan. Salah satu model pembelajaran yang dapat digunakan adalah model pembelajaran berbasis masalah.

Model pembelajaran berbasis masalah adalah pembelajaran berfokus pada permasalahan nyata yang dipilih sehingga siswa tidak saja mempelajari konsepkonsep yang berhubungan dengan masalah tetapi juga metode ilmiah untuk memecahkan masalah tersebut [4]. Penerapan model pembelajaran berbasis masalah ini peserta didik dapat mengembangkan kemampuan berpikir kritis mereka dengan menyusun pengetahuan mereka sendiri. Peserta didik juga dapat menggunakan pengetahuan awal yang mereka miliki untuk mencari informasiinformasi baru yang berkaitan dengan permasalahan yang disajikan selama proses pembelajaran berlangsung, sehingga proses pemecahan masalah dapat lebih mudah dan tepat.

Penelitian yang terkait dengan pengaruh model pembelajaran berbasis masalah terhadap kemampuan berpikir kritis peserta didik yang telah dilakakukan oleh peneliti sebelumnya menyimpulkan bahwa kemampuan berpikir kritis peserta didik yang diberi perlakuan model pembelajaran berbasis masalah lebih tinggi dari peserta didik yang mendapatkan pembelajaran konvensional [5]. Peserta didik pada kelas yang diberi perlakuan model pembelajaran berbasis masalah lebih aktif dalam memecahkan masalah yang diberikan dan guru hanya sebagai fasilitator, sehingga proses pembelajaran murni terfokus pada peserta didik. Peneliti lain yang juga melakukan penelitian terkait pengaruh model pembelajaran berbasis masalah terhadap kemampuan berpikir kritis peserta didik menyimpulkan bahwa model pembelajaran berbasis masalah dapat meningkatkan kemampuan berpikir kritis peserta didik [6]. Kemampuan berpikir kritis peserta didik mengalami peningkatan secara signifikan karena kegiatan belajar di dalam model pembelajaran berbasis masalah mencakup kegiatan untuk melatih kemampuan berpikir kritis peserta didik.

Berdasarkan uraian di atas, maka perlu dilakukan penelitian lebih lanjut dengan judul "Pengaruh Model Pembelajaran Berbasis Masalah dan Pengetahuan Awal terhadap Kemampuan Berpikir Kritis Fisika Peserta Didik Kelas X". Diharapkan dengan diterapkannya model pembelajaran berbasis masalah dan pengetahuan awal peserta didik ini dapat memberikan pengaruh terhadap kemampuan berpikir kritis Fisika peserta didik kelas X. 


\section{METODE PENELITIAN}

Penelitian ini menggunakan penelitian kuasi eksperimen yang ditujukan untuk mendapatkan informasi yang diperoleh dengan melakukan eksperimen yang sebenarnya dalam keadaan yang tidak memungkinkan untuk memanipulasi semua variabel yang relevan [7].

Rancangan penelitian yang digunakan adalah rancangan faktorial 2 x 2 . Rancangan faktorial (factorial design) ini digunakan apabila peneliti mempertimbangkan variabel bebas lain (biasanya variabel moderator) dalam penelitiannya [8].

Tabel 1 Rancangan Faktorial 2 x 2

\begin{tabular}{lccc}
\hline & B & \multicolumn{2}{c}{ Model Pembelajaran (B) } \\
\cline { 3 - 4 } A & & Berbasis Masalah $\left(\mathrm{B}_{1}\right)$ & Konvensional $\left(\mathrm{B}_{2}\right)$ \\
\hline Pengetahuan & Tinggi $\left(\mathrm{A}_{1}\right)$ & $\mathrm{A}_{1} \mathrm{~B}_{1}$ & $\mathrm{~A}_{1} \mathrm{~B}_{2}$ \\
\cline { 3 - 4 } Awal (A) & Rendah $\left(\mathrm{A}_{2}\right)$ & $\mathrm{A}_{2} \mathrm{~B}_{1}$ & $\mathrm{~A}_{2} \mathrm{~B}_{2}$ \\
\hline
\end{tabular}

Diadaptasi dari Setyosari (2015:215).

Populasi dalam penelitian ini adalah seluruh peserta didik kelas X MIA SMA Negeri 1 Kediri tahun ajaran 2018/2019 yang berjumlah 73 peserta didik yang terbagi ke dalam 3 kelas. Teknik pengambilan sampel dalam penelitian ini yaitu menggunakan teknik cluster random sampling. Teknik kelompok atau rumpun (cluster) digunakan apabila populasi atau sampel yang tersedia adalah berupa unitunit rumpun dalam populasi [8]. Sampel dalam penelitian ini adalah kelas X MIA 1 sebagai kelas eksperimen dan kelas X MIA 2 sebagai kelas kontrol.

Data pengetahuan awal peserta didik dikumpulkan dengan menggunakan tes tulis berupa pilihan ganda. Data yang dikumpulkan dari tes pengetahuan awal peserta didik ini digunakan untuk mengkategorikan peserta didik yang memiliki pengetahuan awal tinggi dan pengetahuan awal rendah dan pengumpulan data kemampuan berpikir kritis peserta didik dikumpulkan dengan menggunakan tes tulis berupa tes uraian.

\section{HASIL DAN PEMBAHASAN}

Penelitian ini bertujuan untuk mengetahui pengaruh model pembelajaran dan pengetahuan awal terhadap kemampuan berpikir kritis Fisika peserta didik kelas X MIA di SMAN 1 Kediri tahun ajaran 2018/2019. Data yang diperoleh merupakan nilai tes pengetahuan awal dan nilai tes kemampuan berpikir kritis peserta didik di kelas eksperimen dan kelas kontrol. 
Pengetahuan awal yang dimiliki peserta didik diukur dengan menggunakan instrumen tes pengetahuan awal berupa 22 soal pilihan ganda. Tes pengetahuan awal ini diberikan sebelum pembelajaran dimulai. Berdasarkan hasil tes pengetahuan awal peserta didik, didapatkan nilai tertinggi di kelas eksperimen dan kelas kontrol adalah 68 dan 64, sedangkan nilai terendah di masing-masing kelas adalah 18 dan 14. Nilai rata-rata tes pengetahuan awal yang didapatkan di kelas eksperimen sebesar 41,81 dan di kelas kontrol sebesar 41,71. Data hasil tes pengetahuan awal peserta didik dapat dilihat pada Gambar 1.

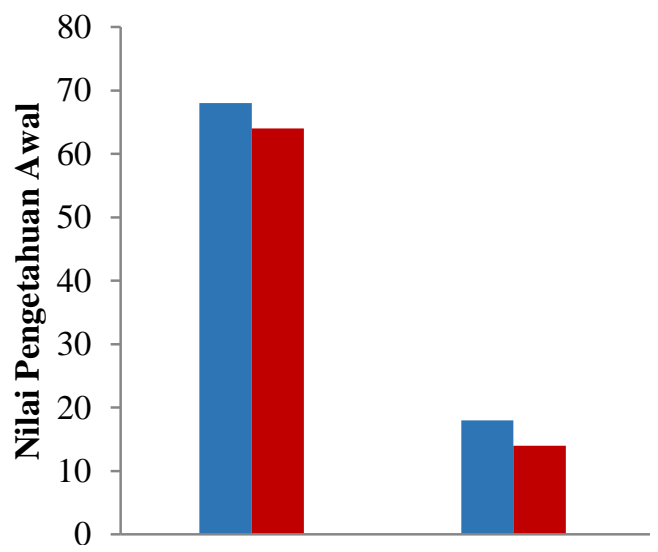

Gambar 1 Hasil Tes Pengetahuan Awal Peserta Didik.

Nilai-nilai tes pengetahuan awal yang telah didapatkan kemudian digunakan untuk mengelompokkan peserta didik menjadi 2 kelompok, yaitu peserta didik dengan pengetahuan awal tinggi dan pengetahuan awal rendah. Pengelompokan pengetahuan awal peserta didik dilakukan dengan menggunakan metode belah dua. Pengetahuan awal peserta didik dikategorikan tinggi jika nilainya lebih dari 50 sampai dengan 100 dan dikategorikan rendah jika nilainya 1 sampai dengan 50 .

Kemampuan berpikir kritis peserta didik diuji dengan menggunakan instrumen tes kemampuan berpikir kritis berupa 10 soal uraian. Nilai tertinggi di kelas eksperimen dan kelas kontrol adalah 75 dan 65, sementara nilai terendah di kedua kelas adalah 25. Nilai rata-rata kelas eksperimen dan kelas kontrol adalah 51,79 dan 43,80. Data nilai tes kemampuan berpikir kritis peserta didik dapat dilihat pada Gambar 2. 


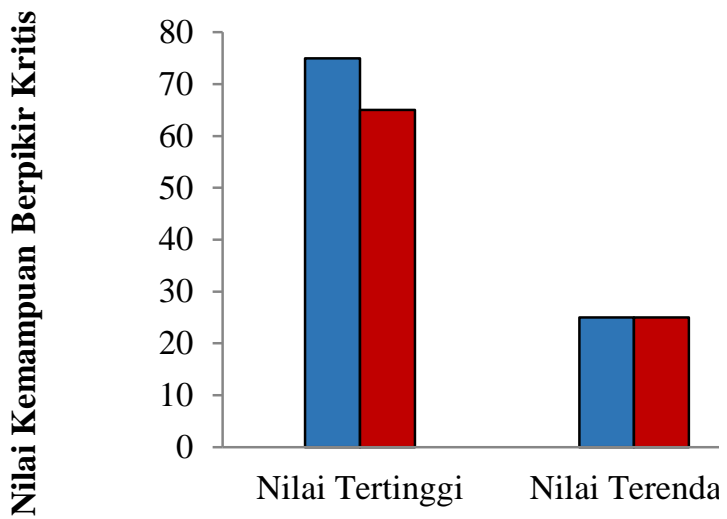

Gambar 2 Hasil Tes Kemampuan Berpikir Kritis Peserta Didik.

Gambar 2 menunjukkan bahwa peserta didik dikelas eksperimen memiliki nilai rata-rata kemampuan berpikir kritis yang lebih tinggi daripada nilai rata-rata peserta didik di kelas kontrol. Nilai-nilai tes kemampuan berpikir kritis peserta didik kemudian dikelompokkan berdasarkan kategori pengetahuan awal yang telah didapatkan sebelumnya, sehingga diperoleh nilai rata-rata kemampuan berpikir kritis dari peserta didik yang memiliki pengetahuan awal tinggi dan pengetahuan awal rendah dari masing-masing kelas.

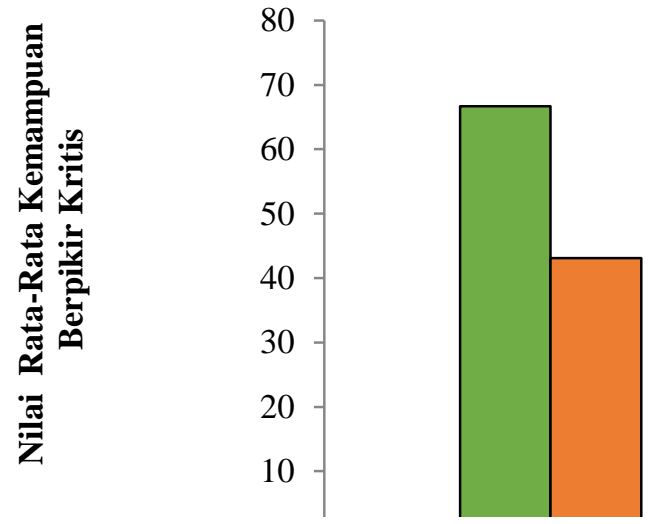

Gambar 3 Nilai Rata-Rata Kemampuan Berpikir Kritis Berdasarkan Pengetahuan Awal Peserta Didik.

Peserta didik yang memiliki pengetahuan awal tinggi di kelas eksperimen mendapatkan nilai rata-rata kemampuan berpikir kritis sebesar 66,71 dan di kelas kontrol didapatkan nilai rata-rata kemampuan berpikir kritis sebesar 50,12, sedangkan nilai kemampuan berpikir kritis peserta didik yang memiliki 
pengetahuan awal rendah di kelas eksperimen didapatkan nilai rata-rata sebesar 43,08 dan di kelas kontrol didapatkan nilai rata-rata sebesar 39,92. Nilai rata-rata untuk kedua kelas ditunjukkan pada Gambar 3.

Gambar 3 menunjukkan bahwa nilai rata-rata kemampuan berpikir kritis peserta didik yang memiliki pengetahuan awal tinggi di kelas eksperimen lebih tinggi daripada peserta didik yang memiliki pengetahuan awal tinggi di kelas kontrol, begitu juga dengan nilai rata-rata kemampuan berpikir kritis peserta didik yang memiliki pengetahuan awal rendah di kelas eksperimen lebih tinggi daripada peserta didik yang memiliki pengetahuan awal rendah di kelas kontrol.

Uji homogenitas dilakukan pada tes pengetahuan awal dan tes kemampuan berpikir kritis peserta didik. Uji homogenitas dapat menggunakan rumus uji-F [9], seperti berikut:

$$
\mathbf{F}=\frac{\text { varians terbesar }}{\text { varians terkecil }}
$$

Hasil uji homogenitas pada tes pengetahuan awal dan tes kemampuan berpikir kritis peserta didik dapat dilihat pada Tabel 1 berikut.

Tabel 1 Hasil Uji Homogenitas Pengetahuan Awal (PA) dan Kemampuan Berpikir Kritis (KBK) Kelas Kontrol dan Kelas Eksperimen

\begin{tabular}{clllll}
\hline Tes & \multicolumn{1}{c}{ Kelas } & $\mathbf{N}$ & $\mathbf{F}_{\text {hitung }}$ & $\mathbf{F}_{\text {tabel }}$ & Kriteria \\
\hline \multirow{2}{*}{ PA } & Kontrol & 21 & \multirow{2}{*}{1,31} & & \\
\cline { 2 - 3 } & Eksperimen & 19 & & \multirow{2}{*}{2,12} & Homogen \\
KBK & Kontrol & 21 & \multirow{2}{*}{1,75} & & \\
\cline { 2 - 3 } & Eksperimen & 19 & & & \\
\hline
\end{tabular}

Berdasarkan hasil Tabel 1 terlihat bahwa uji homogenitas pengetahuan awal peserta didik kelas kontrol dan kelas eksperimen didapatkan nilai $\mathrm{F}_{\text {hitung }}<$ $\mathrm{F}_{\text {tabel, }}$, ini menunjukkan bahwa kedua kelas memiliki kemampuan awal yang sama atau homogen.

Tabel 2 Hasil Uji Normalitas Pengetahuan Awal (PA) dan Kemampuan Berpikir Kritis (KBK) Kelas Kontrol dan Kelas Eksperimen

\begin{tabular}{clccc}
\hline Tes & \multicolumn{1}{c}{ Kelas } & $\chi_{\text {hitung }}^{2}$ & \multicolumn{1}{c}{$\chi_{\text {tabel }}^{2}$} & \multicolumn{1}{c}{ Kriteria } \\
\hline \multirow{2}{*}{ PA } & Kontrol & 10,254 & & \\
& Eksperimen & 10,740 & \multirow{2}{*}{11,070} & Terdistribusi \\
\multirow{2}{*}{ KBK } & Kontrol & 5,150 & & Normal \\
& Eksperimen & 3,769 & & \\
\hline
\end{tabular}


Uji normalitas dapat dicari menggunakan rumus uji chi kuadrat [10]. Berdasarkan hasil uji normalitas pengetahuan awal dan kemampuan beripikir kritis peserta didik dapat dilihat di Tabel 2.

Tabel 2 menunjukkan bahwa semua data yang diperoleh dari tes pengetahuan awal dan tes kemampuan berpikir kritis di kelas kontrol dan kelas eksperimen terdistribusi normal. Data dikatakan terdistribusi normal apabila $\chi_{\text {hitung }}^{2}<\chi_{\text {tabel }}^{2}$, nilai $\chi_{\text {hitung }}^{2}$ kedua kelas yang diperoleh dari tes pengetahuan awal adalah sebesar 10,254 untuk kelas kontrol dan 10,740 untuk kelas eksperimen dengan nilai $\chi_{\text {tabel }}^{2}$ sebesar 11,070 , sedangkan nilai $\chi_{\text {hitung }}^{2}$ kedua kelas yang diperoleh dari tes kemampuan berpikir kritis yaitu sebesar 5,150 untuk kelas kontrol dan 3,769 untuk kelas eksperimen dengan nilai $\chi_{\text {tabel }}^{2}$ sebesar 11,070 .

Hasil uji homogenitas dan normalitas kedua data menunjukkan bahwa data yang diperoleh homogen dan terdistribusi normal. Uji hipotesis yang digunakan dalam penelitian ini adalah uji anava dua jalan. Hasil analisis uji hipotesis dapat dilihat pada Tabel 3.

Tabel 3 Ringkasan Hasil Uji Anava Dua Jalan

\begin{tabular}{cccccc}
\hline Sumber Variasi & Db & $\begin{array}{c}\text { Jumlah } \\
\text { Kuadrat }\end{array}$ & $\begin{array}{c}\text { Rerata antar } \\
\text { Group }\end{array}$ & $F_{\text {hitung }}$ & $F_{\text {tabel }}$ \\
\hline Antar Kolom & 1 & 636 & 636 & 4,48 & \multirow{2}{*}{4,06} \\
\hline Antar Baris & 1 & 2530 & 2530 & 17,82 & \\
\hline Interaksi & 1 & 454 & 454 & 3,2 & \\
\hline Dalam & 36 & 5120 & 142 & & \\
\hline Total & 39 & 8740 & & & \\
\hline
\end{tabular}

Hipotesis akan diterima jika nilai $F_{\text {hitung }} \geq F_{\text {tabel }}$, dengan harga $F_{\text {tabel }}=4,06$ pada taraf signifikan $5 \%$. Hasil uji hipotesis terkait pengaruh model pembelajaran berbasis masalah dengan sumber variasi antar kolom didapatkan $F_{\text {hitung }}=4,48$, sehingga diketahui bahwa $F_{\text {hitung }} \geq F_{\text {tabel }}$. Hal ini menunjukkan bahwa $H_{a 1}$ diterima dan $H_{01}$ ditolak, artinya ada pengaruh model pembelajaran berbasis masalah terhadap kemampuan berpikir kritis Fisika peserta didik kelas X. Hasil uji hipotesis terkait pengetahuan awal peserta didik dengan sumber variasi antar baris didaptkan nilai $F_{\text {hitung }}=17,82$, sehingga dapat diketahui bahwa $F_{\text {hitung }} \geq F_{\text {tabel }}$. Hal ini menunjukkan bahwa $H_{a 2}$ diterima dan $H_{02}$ ditolak, artinya ada pengaruh pengetahuan awal dengan kategori pengetahuan awal tinggi dan pengetahuan awal rendah terhadap kemampuan berpikir kritis Fisika peserta didik kelas X. Hasil uji hipotesis terkait interaksi antara model pembelajaran 
berbasis masalah dan pengetahuan awal didapatkan hasil $F_{\text {hitung }}=3,2$, sehingga dapat diketahui bahwa $F_{\text {hitung }}<F_{\text {tabel }}$, hal ini menunjukkan bahwa $H_{a 3}$ ditolak dan $H_{03}$ diterima, artinya tidak ada interaksi antara model pembelajaran berbasis masalah dan pengetahuan awal terhadap kemampuan berpikir kritis fisika peserta didik kelas X. Hasil interaksi model pembelajaran berbasis masalah dan pengetahuan awal terhadap kemampuan berpikir kritis Fisika disajikan pada grafik seperti Gambar 4.

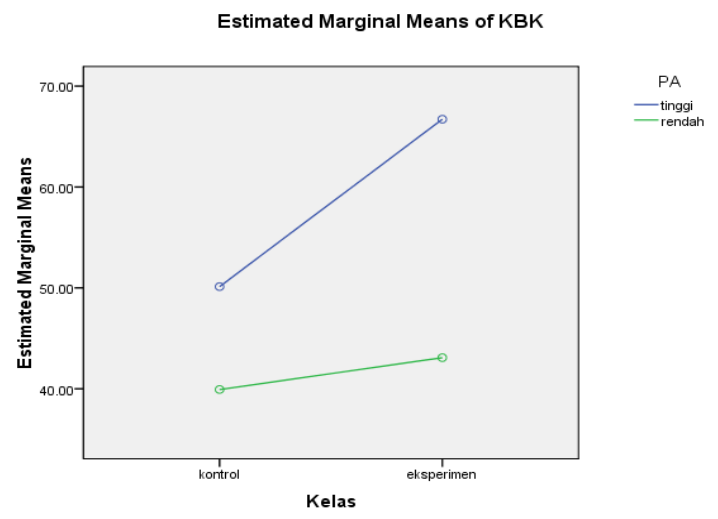

Gambar 4 Interaksi antara Model Pembelajaran Berbasis Masalah dan Pengetahuan Awal Terhadap Kemampuan Berpikir Kritis Fisika Peserta Didik.

Gambar di atas menjelaskan bahwa tidak ada interaksi antara model pembelajaran berbasis masalah dan pengetahuan awal terhadap kemampuan berpikir kritis Fisika peserta didik.

\section{Pengaruh Model Pembelajaran Berbasis Masalah terhadap Kemampuan Berpikir Kritis Fisika Peserta Didik}

Analisis uji hipotesis pertama diperoleh nilai $F_{\text {hitung }}>F_{\text {tabel, }}$ sehingga hipotesis alternatif pertama $\left(H_{a 1}\right)$ diterima, maka dapat disimpulkan bahwa ada pengaruh model pembelajaran berbasis masalah terhadap kemampuan berpikir kritis Fisika peserta didik kelas X. Data hasil penelitian pada kelas eksperimen dan kelas kontrol menunjukkan bahwa nilai rata-rata kemampuan berpikir kritis di kelas eksperimen yang menerapkan model pembelajaran berbasis masalah lebih tinggi daripada nilai rata-rata kemampuan berpikir kritis di kelas kontrol yang menerapkan model pembelajaran konvensional.

Proses pembelajaran dalam model pembelajaran berbasis masalah ini dimulai dengan disajikannya permasalahan nyata yang terdapat pada fase pertama, dimana peneliti memperkenalkan fenomena-fenomena yang sering terjadi di 
kehidupan sehari-hari terkait dengan materi yang akan di pelajari. Kegiatan pada fase ini peneliti dapat memfokuskan peserta didik pada pertanyaan-pertanyaan yang berkaitan dengan fenomena-fenomena yang disajikan, hal ini dapat membantu peserta didik untuk memenuhi indikator pertama berpikir kritis, yaitu klarifikasi dasar.

Fase kedua yaitu mengorganisasi peserta didik untuk belajar dengan cara membentuk kelompok bersama teman sekelasnya. Peserta didik akan bekerja sama untuk mencari informasi-informasi baru dan membangun pengetahuan mereka dengan cara bereksperimen, berdiskusi, dan memberikan pendapat berdasarkan pengalaman yang mereka miliki. Kegiatan pada fase ini dapat membantu peserta didik untuk memenuhi beberapa indikator berpikir kritis, seperti klarifikasi dasar dan keputusan dasar. Peserta didik akan mengumpulkan informas-informasi baru untuk mengidentifikasi berbagai kemungkinan yang dapat terjadi terkait permasalahan-permasalahan yang disajikan, selain itu peserta didik juga dapat memberikan alasan-alasan yang jelas terkait pemecahan masalah yang diambil.

Fase ketiga yaitu membimbing pengetahuan individu/kelompok. Pada fase ini peserta didik dituntut untuk mengumpulkan informasi terkait materi Fisika yang dipelajari dengan cara melakukan eksperimen. Eksperimen yang dilakukan membantu peserta didik bekerja secara aktif untuk mencari solusi dari permasalahan yang disajikan. Hasil eksperimen yang didapatkan membantu peserta didik untuk mendapatkan penjelasan yang sesuai, membantu peserta didik dalam membuat solusi dari permasalahan yang disajikan, serta membantu peserta didik untuk menarik kesimpulan yang tepat terkait dengan materi Fisika yang dipelajari. Kegiatan pada fase ini membantu peserta didik untuk memenuhi indikator berpikir kritis, seperti keputusan dasar, inferensi, serta menalar dan pengintegrasian.

Fase keempat yaitu mengembangkan dan menyajikan hasil karya. Pada fase ini setiap kelompok menyajikan hasil eksperimen yang didapatkan dengan cara mempresentasikan hasil penelitiannya di hadapan semua teman sekelasnya, dengan demikian anggota kelompok lain dapat mengetahui pemecahan masalah yang diambil benar atau salah. Pada kegiatan ini peserta didik melatih kemampuan berpikir kritisnya untuk memenuhi indikator penjelasan lebih lanjut, serta menalar dan pengitegrasian. Peserta didik dapat mempertimbangkan suatu definisi berdasarkan hasil ekperimen yang didapatkan kelompoknya dan hasil ekperimen yang dipresentasikan kelompok lain, serta mempertimbangkan pendapat dari kelompok lain untuk lebih memahami pengetahuan baru yang didapatkan selama proses pembelajaran berlangsung.

Fase terakhir yaitu menganalisis dan mengevaluasi proses pemecahan masalah. Peniliti membantu peserta didik melakukan refleksi terhadap pengetahuan 
baru yang mereka dapatkan selama proses pembelajaran, sehingga peserta didik mengetahui kejelasan dari pengetahuan baru tersebut. Kegiatan pembelajaran pada fase ini dapat membantu peserta didik memenuhi indikator berpikir kritis, yaitu penjelasan lebih lanjut. Pada fase ini peneliti berperan dalam memberikan penjelasan lanjut terkait materi Fisika yang dipelajari peserta didik.

Kegiatan peserta didik selama proses pembelajaran yang telah diuraikan dalam beberapa paragraf di atas, menunjukkan bahwa model pembelajaran berbasis masalah yang diterapkan pada kelas eksperimen memiliki pengaruh terhadap kemampuan berpikir kritis Fisika peserta didik. Fakta ini sejalan dengan penelitian yang menyimpulkan bahwa model pembelajaran berbasis masalah membuat peserta didik lebih aktif sehingga kemampuan berpikir kritisnya jauh lebih tinggi dibandingkan dengan pembelajaran yang menggunakan model konvensional [11].

\section{Pengaruh Pengetahuan Awal terhadap Kemampuan Berpikir Kritis Fisika Peserta Didik}

Analisis uji hipotesis kedua diperoleh nilai $\mathrm{F}_{\text {hitung }}>\mathrm{F}_{\text {tabel }}$, sehingga hipotesis alternatif kedua $\left(H_{a 2}\right)$ diterima, maka dapat disimpulkan bahwa ada pengaruh pengetahuan awal terhadap kemampuan berpikir kritis Fisika peserta didik kelas X. Data hasil penelitian pada kelas eksperimen dan kelas kontrol menunjukkan bahwa peserta didik dengan pengetahuan awal tinggi memiliki nilai rata-rata kemampuan berpikir kritis lebih tinggi daripada peserta didik dengan pengetahuan awal rendah.

Peserta didik dengan pengetahuan awal tinggi dapat belajar dengan baik di kelas, mereka dapat memfokuskan diri pada pertanyaan-pertanyaan yang diajukan. Peserta didik dapat mempertimbangkan jawaban atau solusi dari pertanyaanpertanyaan tersebut dengan mengandalkan pengetahuan awal yang dimilikinya dan pengetahuan baru yang didapatkannya, serta memberikan alasan-alasan yang jelas dari solusi yang mereka ambil. Hal ini menunjukkan bahwa peserta didik dengan pengetahuan awal tinggi dapat memenuhi indikator berpikir kritis terkait klarifikasi dasar dan keputusan dasar dengan baik.

Peserta didik dengan pengetahuan awal tinggi dapat menalar berbagai kemungkinan dan menemukan alasan yang jelas terkait kemungkinan-kemungkinan tersebut, peserta didik juga dapat dengan mudah membuat kesimpulan berdasarkan fakta-fakta yang mereka kumpulkan selama proses pembelajaran berlangsung. Pengetahuan awal yang memadai dapat membantu peserta didik menyusun pengetahuan awal yang dimilikinya dan informasi-informasi baru yang didapatkannya. Fakta ini sesuai dengan pendapat pengetahuan awal memiliki peran yang sangat besar dalam pengkonstruksian peserta didik terhadap informasi baru 
yang didapatkan peserta didik [12]. Pengetahuan awal yang dimiliki oleh peserta didik saling terkait dengan pengetahuan baru yang diterima selama proses pembelajaran berlangsung, sehingga peserta didik dengan pengetahuan awal tinggi dapat menalar, mengintegrasi, dan membuat inferensi materi dengan baik.

Peserta didik dengan pengetahuan awal tinggi cenderung memiliki rasa ingin tahu yang besar terhadap informasi-informasi baru yang diterimanya, pengetahuan awal yang mereka miliki digunakan untuk mencari kebenaran dari informasiinformasi baru tersebut. Fakta ini sejalan dengan pendapat yang mengatakan bahwa pengetahuan awal dapat berfungsi untuk mempermudah dan mengoptimalkan informasi yang diperoleh, serta pengorganisasian dan mengungkap pengetahuan baru yang didapatkan peserta didik [13]. Peserta didik dapat dengan mudah memahami berbagai penjelasan dan dapat penjelasan lebih lanjut mengenai berbagai istilah dan mempertimbangkan definisi dari istilah-istilah tersebut.

\section{Interaksi antara Pengaruh Model Pembelajaran Berbasis Masalah dan Pengetahuan Awal terhadap Kemampuan Berpikir Kritis Fiska Peserta Didik}

Analisis uji hipotesis yang ketiga diperoleh nilai $\mathrm{F}_{\text {hitung }}<\mathrm{F}_{\text {tabel }}$ sehingga hipotesis alternatif ketiga $\left(H_{a 3}\right)$ ditolak yang artinya tidak ada interaksi antara model pembelajaran berbasis masalah dan pengetahuan awal terhadap kemampuan berpikir kritis Fisika peserta didik kelas X. Hasil uji hipotesis membuktikan bahwa model pembelajaran berbasis masalah berpengaruh terhadap kemampuan berpikir kritis peserta didik, selain itu pengetahuan awal juga berpengaruh terhadap kemampuan berpikir kritis peserta didik, tetapi model pembelajaran berbasis masalah dan pengetahuan awal tidak saling berinteraksi karena kedua variabel tersebut tidak saling mempengaruhi terhadap kemampuan berpikir kritis peserta didik. Peserta didik dengan pengetahuan awal tinggi memiliki rasa ingin tahu yang tinggi sehingga mereka berperan aktif selama kegiatan pembelajaran untuk mencari tahu berbagai informasi baru yang terkait pengetahuan awal yang mereka miliki, selain itu penerapan model pembelajaran berbasis masalah membuat kegiatan pembelajaran lebih terarah dan dapat membantu peserta didik mengembangkan pengetahuannya secara mandiri. Peserta didik dengan pengetahuan awal rendah cenderung mengandalkan temannya yang lain untuk menyelesaikan pekerjaan karena memiliki pengetahuan awal yang minim terkait materi yang dipelajari, sehingga mereka menjadi pasif selama kegiatan pembelajaran berlangsung. Fakta ini sejalan dengan penelitian yang menyimpulkan bahwa tidak ada interaksi antara model pembelajaran yang digunakan dan pengetahuan awal dalam mempengaruhi kemampuan berpikir kritis peserta didik [14]. Peserta didik dengan pengetahuan awal tinggi cenderung mandiri selama proses pembelajaran, sementara peserta 
didik dengan pengetahuan awal rendah cenderung menerima struktur pembelajaran yang sudah ada dan susah untuk terlibat secara aktif selama proses pembelajaran. Peserta didik dengan pengetahuan awal rendah mengalami kesulitan untuk terbiasa dengan sintaks model pembelajaran berbasis masalah yang menuntut peserta didik untuk lebih mandiri dalam menemukan berbagai macam informasi baru.

\section{SIMPULAN DAN SARAN}

Berdasarkan hasil penelitian dan pembahasan, dapat disimpulkan bahwa Terdapat pengaruh penggunaan LKS berbasis inkuiri terbimbing materi elastisitas dan hukum Hooke terhadap hasil belajar siswa secara signifikan yang ditunjukkan nilai sign. yang diperoleh kurang dari 0,05 yaitu 0,000 . Berdasarkan penelitian yang telah dilakukan Pembelajaran dengan menggunakan LKS berbasis inkuiri terbimbing dapat disarankan kepada guru untuk menggunakan LKS berbasis inkuiri terbimbing materi elastisitas dan hukum Hooke untuk meningkatkan hasil belajar siswa. Penerapan LKS berbasis inkuiri terbimbing materi elastisitas dan hukum Hooke perlu disediakan waktu yang memadai.

\section{UCAPAN TERIMA KASIH}

Terima kasih kepada Ibu Satutik Rahayu, M. Pd., selaku Dosen Pembimbing I dan Ibu Ni Nyoman Sri Putu Verawati, M. Pd., selaku Dosen Pembimbing II, yang selalu sabar dan ikhlas dalam membimbing penulis hingga jurnal ini dapat terselesaikan dengan baik.

\section{DAFTAR PUSTAKA}

[1] Latifa, B. R. A., Verawati, N. N. S. P., Harjono, A. 2017. Pengaruh Model Pembelajaran Learning Cycle 5E (Engage, Explore, Explain, Elaboration, \& Evaluate) terhadap Kemampuan Berpikir Kritis Peserta Didik Kelas X MAN 1 Mataram. Jurnal Pendidikan Fisika dan Teknologi, 3(1):61-67.

[2] Ennis, R. H. 2011. The Nature of Critical Thinking: An Outline of Critical Thinking Disposition and Abilities. University of Illinois. On line at http://faculty.education.illinois.edu/rhennis/documents/TheNatureofCriticalThinking 51711 000.pdf [diakses tanggal 01 Januari 2018].

[3] Jannah', S. N., Doyan, A., \& Harjono, A. 2015. Pengaruh Model Pembelajaran Kooperatif Pendekatan Problem Posing ditinjau dari Pengetahuan Awal Terhadap Kemampuan Pemecahan Masalah Fisika peserta didik SMK. Jurnal Pendidikan Fisika dan Teknologi, 4(1):256-263.

[4] Azmi, M. K., Rahayu, S., \& Hikmawati. Pengaruh Model Problem Based Learning dengan Metode Eksperimen dan Diskusi Terhadap Hasil Belajar Fisika Ditinjau dari Sikap Ilmiah Siswa Kelas X MIPA SMA N 1 Mataram. Jurnal Pendidikan Fisika dan Teknologi, 2(2):86-94. 
[5] Santoso, R., Darmadi, I. W., \& Darsikin, D. 2016. Pengaruh Model Pembelajaran Berbasis Masalah Berbantuan Media Komputer terhadap Kemampuan Berpikir Kritis peserta didik SMA Negeri 5 Palu. Jurnal Pendidika Fisika Tadulako Online (JPFT), 4(1):39-44.

[6] Setyorini, U., Sukiswo, S. E., \& Subali, B. 2011. Penerapan Model Problem Based Learning untuk Meningkatkan Kemampuan Berpikir Kritis Siswa SMP. Jurnal Pendidikan Fisika Indonesia 7:52-56.

[7] Trianto, T. 2010. Pengantar Penelitian Pendidikan Bagi Pengembangan Profesi Pendidikan dan Tenaga Kependidikan. Jakarta: Kencana.

[8] Setyosari, P. 2015. Metode Penelitian Pendidikan Dan Pengembangan. Jakarta: Kencana.

[9] Sundayana, R. 2015. Statistika Penelitian Pendidikan. Bandung: Alfabeta.

[10] Riduwan, R. 2014. Dasar-dasar Statistika. Bandung: Alfabeta.

[11] Fatimah, N., Gunawan, G., \& Wahyudi, W. 2016. Pembelajaran Berbasis Masalah dengan Strategi Konflik Kognitif terhadap Penguasaan Konsep dan Kemampuan Berpikir Kritis Fisika Kelas XI SMKN 1 Lingsar Tahun Pelajaran 2014/2016. Jurnal Pendidikan Fisika dan Teknologi, 2(4):183-190.

[12] Rufaida, S., \& Sujiono, E. H. 2013. Pengaruh Model Pembelajaran dan Pengetahuan Awal terhadap Kemampuan Pemecahan Masalah Fisika Peserta Didik Kelas XI IPA MAN 2 Model Makasar. Jurnal Pendidikan IPA Indonesia, 2(2):161-168.

[13] Razak, F. 2017. Hubungan Kemampuan Awal terhadap Kemampuan Berpikir Kritis Matematika pada Siswa Kelas VII SMP Pesantren Immim Putri Minasatene. Jurnal Mosharafa, 6(1):117-128.

[14] Danial, M. 2017. Pengaruh Model Pembelajaran dan Kemampuan Awal terhadap Kemampuan Berpikir Kritis dan Pemahaman Konsep Peserta Didik. Journal of Educational Science and Technology, 3(1):18-32.

[15] Bahtiar, Y S Rahayu, \& Wasis. 2018. Developing Learning Model P3E to Improve Students' Critical Thinking Skills of Islamic Senior High School. IOP Conf. Series: Journal Of Physics: Conf. Series 947(2018)012067. 